\title{
TOTIUS AND THE IMAGERY OF DOOM AND IMPERIAL DESTRUCTION
}

\author{
S Sharland (University of KwaZulu-Natal, Durban)
}

The South African poet J D du Toit, popularly known as Totius (1877-1953), published collections of personal, religious and political poetry, inspired by the struggles of the Afrikaner people after the South African War or Second Boer War (1899-1902). Although the poet enjoyed a Classical education, firstly as a child at a German mission school, and subsequently in his Theological studies, Classical influence on Totius' work has not been considered to date. This article investigates two poems for their possible Classical precedents. In the first, Totius considers but ultimately rejects the idea of the river Lethe as a way of forgetting his personal tragedies. In the second, he compares the disaster the Afrikaners experienced in the South African War to a roadside thorn-tree that is destroyed by a passing ox-wagon, here representing British imperialism. This may have a precedent in the destruction of the flower cut down by a plough at the edge of the meadow (Catullus 11.21-24), the political dimensions of which coincide with Totius' anti-imperialist sentiments. Although the Biblical, Christian paradigm is dominant in Totius' writing, this article suggests that the Classical world was an alternative source of inspiration for this poet.

Keywords: Totius (J D du Toit); Classics and South Africa; Afrikaans poetry; Lethe; memory and forgetting; Catullus; anti-imperialist discourse

The South African poet and theologian Jakob Daniël du Toit (1877-1953), popularly known as Totius, ${ }^{1}$ was the author of a number of collections of personal, religious and political poetry, including the first-ever book of verse published in the Afrikaans language. ${ }^{2}$ His oeuvre focuses primarily on his relationships with members of his family, on expressions of his Christian faith, and on the struggle of

1 Although J D du Toit's first poems were published under the name Jaduto (an acronym derived from the first letters of his first name and surname), from 1905 he replaced this with the nom du plume Totius (D'Assonville 1993:187). It is likely that he derived this Latinate version of his surname from a nickname given him by other students when he was studying for his doctorate at the Vrije Universiteit in Amsterdam in the Netherlands (D’Assonville 2003:51).

2 This work was Totius' By die Monument published in 1908. The monument in question is the South African Vrouemonument (National Women's Memorial) in Bloemfontein, which commemorates the women and children who died in British concentration camps during the South African War (Second Anglo-Boer War). Collection of funds for the Monument commenced in 1907, and the memorial was officially opened in 1913. 
the Afrikaner people for cultural survival and self-determination in the wake of the South African War (or Second Anglo-Boer War, 1899-1902). An activist for the promotion of the Afrikaans language, Totius was closely involved in the first translation of the Bible into Afrikaans, and is known particularly for his verse translations of the Psalms. Imagery in his poetry seems to derive largely from the stark landscape of Africa, its wide open spaces, its fauna and flora, particularly its trees, ${ }^{3}$ but there are also domestic images: the house, the nursery, life on a farm. Where there are any references to historical or literary figures, these are mostly figures from the Bible, like Rachel, the wife of the patriarch Jacob, who provides the title for one of Totius' volumes of verse. ${ }^{4}$ Not for nothing was Totius, who lectured at the fledgling university at Potchefstroom (today the University of the North-West), known as the 'Prophet of the Mooi River' (Profeet van die Mooirivier). ${ }^{5}$

\section{Totius at the Lethe: Classical undercurrents in the poetry of $J D$ du Toit}

Given his strong Christian background, it is surprising to find, in one of the last poems Totius ever wrote,${ }^{6}$ a Classical reference used in a striking manner. I first quote the poem Totius wrote shortly before his death on 1 July 1953, and then give my own English translation. While I have tried to be as accurate in my translation as possible, I have also attempted to preserve Totius' original rhyme scheme:

Trees are a pervasive and significant symbol for Totius, as they are often indicative of both suffering and miraculous regeneration, see e.g. Totius' poems Vergewe en vergeet discussed below, and Die doringbome by die fontein (Venter 1977:307-308 vol. 10). The dense, dark trees with their looming shade at the start of Lei my nie ... are, however, entirely negative and threatening. On trees and other symbols in Totius, see Cloete 1990:77-90, esp. 84-86.

4 Totius' volume Ragel: Opgedra aan die vroue van Suid-Afrika was first published in 1913. Its seventh, revised edition is reprinted at Venter 1977:81-131 (vol. 10). Rachel in this context refers to the Biblical texts Jeremiah 31:15-17 and Matthew 2:16-18, where Rachel is said to be heard weeping for her dead children.

5 After the Theological school of the Reformed Church of South Africa (Gereformeerde Kerk), which was started at Burgersdorp in the Cape, relocated to Potchefstroom on the Mooi ('Pretty', 'Beautiful') River, the institution was for many years known as Die Potchefstroomse Universiteitskollege (Potchefstroom University College), shortened to $P U K$, before acquiring full university status in 1951. The university is now part of the larger University of North-West after it in 2004 merged with a smaller university at Mafikeng.

6 While Lei my nie ... is recognised as Totius' final published poem, many may prefer to believe, along with D'Assonville (1993:239), that an unpublished poem entitled $O p$ my sterwensuur ('In my hour of death'), which has a much more positive tone, was his last poem. 


\section{Lei my nie ...}

Lei my nie langs stille waters waar die Vaalrivier in strome saggies vloei in skemerstond, waar deur digte en donker bome nog verlaas hul skynsel blink.

Lei my nie langs daardie walle, Dat 'k nie aan my leed wéér dink.

Lei my langs die stille waters van die ondergrondse Lethe Dat ek diep daaruit kan drink, en my denke en my wete (yd'le poging tot deurgronding van die diepe sielsverwonding) in dié diepte kan versink.

Maar daar is geen stille waters van ' $n$ Lethe waar ' $k$ my wete en my denke kan verdrink.

Dis 'n skone fantasie.

Kwelgedagtes, dié kan sluimer

of in stilte en slaap versink, maar vergeet, dit kan ek nie!

\section{Lead me not ...}

Lead me not near quiet waters where the Vaal river in currents gently flows at twilight's hour, where through dense, dark trees streams reflect the light so brief. Lead me nowhere near those banks So that I don't recall my grief.

Lead me to the quiet waters of the subterranean Lethe so that deeply I can drink, and my waking thoughts and conscience (a pointless attempt to fathom my soul's deep-wounded chasm) far in those depths can sink.

But there are no quiet waters of a Lethe where I can drown my mind and conscience in the deep. It's an utter fantasy. Troubled thoughts can always slumber Or sink in peacefulness and sleep, but to forget - that cannot be!

This is a strange poem for a Christian writer who usually expresses great faith in God, and derives most of his literary references from Biblical sources. Writing shortly before his death, Totius expresses doubts about his religion and hints at a degree of rebellion against God. The poem's initial words Lei my nie ... ('Lead me

Venter 1977:271 (vol. 10). The poem seems to combine elements of two previous poems by Totius: first, Vergetelheid ('Forgetfulness' or 'Oblivion', Venter 1977:318-319 vol. 10), in which the poet describes himself as living beside a body of water which he says represents forgetfulness or oblivion, but he fails to mention the Lethe or make any other Classical allusions, and, second, Die skemer skuif al deur die digte bome (Venter 1977:466 vol. 10), also possibly one of his last poems, in which the poet describes the threatening approach of the dark through dense trees, and says it makes him reflect sadly and hopelessly on his life. Lei my nie ... is unique, however, for its Classical reference to the Lethe and for its association of the ideas contained in both these previous poems. 
not ...') echo the famous Psalm 23, the second and third verse of which feature the idea of God as the Good Shepherd, leading the psalmist as a shepherd leads sheep. Part of the second verse of the psalm has God leading the psalmist / sheep near quiet or still waters, which Totius (as the translator of the rhymed version of the Psalms for the Reformed hymnal) had himself translated as met sagte hand hul lei langs stille waters. ${ }^{8}$ The poet, however, sounds quite rebellious when he insists that his addressee (who may perhaps be God, the 'Good Shepherd', but also possibly someone else - a human - who may want to take the speaker to an unnamed place) should not lead him near these quiet, restful waters. Apart from sheep, of course, it is the old and infirm who must be led, and at this stage of his life, Totius would probably have included himself with the latter.

The Biblical atmosphere evoked by the first line of the poem is dispelled in the second line, when we hear that it is a South African river - the Vaal - that Totius is firmly rejecting. ' That the Vaal has 'quiet waters' is confirmed in the third line of the poem, where we are told that this river flows softly or gently (saggies) at twilight. ${ }^{10}$ In the first stanza the poet expresses an acute and anxious awareness of the coming dark, which seems to be encroaching as we read these very lines: the waters reflect the last rays of the sun's light, while all around there is already dense blackness. The images of early evening suggest more than just a literal interpretation, implying in addition the twilight of the human lifespan, which the poet is himself experiencing. Night, a metaphor for death, is represented by its harbinger, twilight. The reason the poet does not want to be led along the banks of the Vaal, we find at the end of the first stanza, is that the place makes him recall some personal grief of his (Dat 'k nie aan my leed wéér dink). The stresses on the word wéér (again) in the last line of this stanza imply that this is a repeated occurrence for the poet, and that he cannot take it any longer.

8 See Venter 1977:35, vol. 11. By contrast, the first Afrikaans prose translation of the Psalms for the Afrikaans Bible (1933), also the work of Totius, renders this verse: ... na waters waar rus is, lei Hy my heen ('... towards waters where there is rest, He leads me'). For a study of the relationship between the psalms contained in the original Afrikaans translation of the Bible and the rhymed versions, see Cloete 2000:194-200. Cloete, himself a subsequent translator of the Psalms, observes that Totius' rhymed Psalms tend to reflect earlier Dutch rhymed versions more closely.

9 Ironically, Totius used to love taking long walks beside the Vaal, especially when he was residing at Krugerskraal on the banks of this river. This was the case even in the last two years of his life while he was revising his Bible translations and recovering from his first heart attack (D'Assonville 1993:236). In contrast to the Mooi ('beautiful', 'pretty') river, the term Vaal in Afrikaans means 'drab', 'greyish' or 'dull (in colour)'.

10 The preponderance of liquids, particularly in the poem's initial stanza, cleverly captures the sound of a river. 
In the second stanza we enter the Classical Underworld, as Totius reveals there that the river he wants to be led beside is the subterranean Lethe. That the poet here closely associates the stille waters with the Lethe (stanza 2, lines 1-2) suggests a deliberately polemical juxtaposition of the Biblical and the Classical in this sudden, unanticipated katabasis. Not only does the speaker want to be led beside the Lethe, but he wants to drink deeply from it: Dat ek diep daaruit kan drink (stanza 2, line 3). The Lethe referred to here, in the second lines of both the second and the third stanzas, was the river of forgetfulness, one of the five rivers of the Underworld in Greek mythology, and it was said that all those who drank from the Lethe forgot everything that previously happened to them. ${ }^{11}$ In post-Homeric Classical myth, the shades of the dead had to drink from the waters of the Lethe in order to forget their earthly lives. The Lethe and its waters, source of our word 'lethargic', are often associated with Sleep. At Theogony 758-766 Hesiod explains that Death and his brother Sleep dwell together in the depths of Tartarus. In his 'Myth of Er', Plato (Republic 621a) makes the oblivion caused by the Lethe a prerequisite for reincarnation. Unlike later writers, Plato imagines this river as located on a hot plain lacking any trees or vegetation. ${ }^{12}$ Likewise Virgil at Aeneid 6.748-751 suggests that it is only after drinking the waters of the Lethe that purified souls would want to return to life on earth. Ovid in his Metamorphoses (11.592-604) describes the deeply silent cave where Sleep dwells, whence the soporific river of forgetfulness emerges: 'Near the Cimmerian country is a cave, deeply recessed, a hollow mountainside, the secret dwelling place of languid Sleep ... but from the depths of the rocky cave flows the river of Lethe whose waters invite slumber as they glide, murmuring over whispering pebbles'. ${ }^{13}$

Why is Totius suddenly expressing such a desire to drink the waters of the Lethe? While the poet's strict Calvinist religion ${ }^{14}$ argues against the possibility of reincarnation as his goal, it is clear from the poem that it is oblivion that he seeks.

11 The Greek word lethe means 'forgetting' or 'forgetfulness'. The other four rivers of the Greek Underworld were the Styx (the river of hatred), Acheron (the river of sorrow), Cocytos (the river of lamentation), and Phlegethon (the river of fire).

12 Plato here locates the river on the 'plain of Lethe', but calls the river itself the 'river of Unconcern'. Er records that the foolish drank more than the wise from this river; he himself was forbidden to drink from it, hence his ability to recollect the circumstance.

13 Est prope Cimmerios longo spelunca recessu, / mons cavus, ignavi domus et penetralia Somni ... saxo tamen exit ab imo / rivus aquae Lethes, per quem cum murmure labens / invitat somnos crepitantibus unda lapillis (Ovid Met. 592-593; 602-604). English translation by Innes 1955:262.

14 Although André du Toit questions the accuracy of the appellation 'Calvinist' when applied to most South African religious groups, he does acknowledge that Totius' group, the Gereformeerde Kerk or 'Doppers', have been most nearly 'Calvinist' in the true sense of the word (Du Toit 1985:213-214). 
Totius may have been inspired to think about the Lethe by a post-Classical source, ${ }^{15}$ since what stands out in these later writers is, in particular, how tempting and attractive the idea of oblivion offered by Lethe appears. Shakespeare, one of Totius' favourite authors, ${ }^{16}$ often mentions Lethe and its attractiveness. ${ }^{17}$ At Paradise Lost (2.582-586), Milton, who was greatly admired by Totius, ${ }^{18}$ describes the lure of the Lethe in contrast to the other four rivers of the Underworld:

Far off from these a slow and silent stream,

Lethe, the River of Oblivion, rolls

Her wat'ry labyrinth, whereof who drinks

Forthwith his former state and being forgets,

Forgets both joy and grief, pleasure and pain. ${ }^{19}$

The oblivion that Totius longs for in the poem Lei my nie ... is closely tied to the grief (in Afrikaans, leed) that he mentions in the last line of the first stanza, of which the quiet waters of the Vaal remind him. With many poets, it would be wrong to try to associate a reference to grief with particular events in the writer's own life, but Totius' writing is highly autobiographical. Therefore the grief mentioned in this poem is very likely a reference to the great personal loss experienced by Totius and his family when holidaying on their smallholding Krugerskraal on the banks of the Vaal River on New Year's Eve 1920: their elder

15 Although Totius does show some knowledge of Dante's underworld, devoting at least two articles to it in Die Kerkblad (18 May and 1 June 1926, Venter 1977:463-467, vol. 6), he admits to deriving most of his knowledge from a secondary source (Venter 1977:466), and is also highly critical of Dante's vision. Unlike Dante, who makes the Lethe wash the memory of sins away (see discussion of Coassin 2000:95-96), Totius' Lethe is possibly more straightforwardly 'Classical' as it is described simply a source of oblivion.

16 Totius is recorded as even having read Shakespeare while acting as chaplain to the commandoes in the veld during the Boer War (D'Assonville 1993:186).

17 For example, at Twelfth Night (4.1.59-62), Sebastian refers to the appeal of the river of forgetfulness: 'What relish is this? How runs the stream? / Or I am mad or else this is a dream. / Let fancy still my sense in Lethe steep: / if this be to dream, still let me sleep'.

18 Totius refers extensively to Milton in his paper entitled Die digter as siener ('The poet as seer'), which was delivered at the annual general meeting of the South African Academy in 1911 (Venter 1977:1-2, vol. 10; D'Assonville 1993:121).

19 A few lines later, Milton mentions that the souls of the damned are punished by being ferried repeatedly to and fro over the Lethe, and strongly desire, but are ultimately prevented, from touching the waters of the river of oblivion: 'They ferry over this Lethean Sound / Both to and fro, their sorrow to augment, / And wish and struggle, as they pass, to reach / The tempting stream, with one small drop to loose / In sweet forgetfulness all pain and woe' (Paradise Lost 2.604-608). 
daughter Wilhelmina died instantly when she was struck by lightning during an electric storm..$^{20}$ About two months before, the family had had to watch helplessly as their youngest son, François, who was just over a year old, slowly succumbed to meningitis in their house in Potchefstroom. ${ }^{21}$ The loss of two of his children in such a short space of time was almost unbearable for Totius. He privately poured out his grief in a number of poems on the subject, which were collected and published some years later in a volume entitled Passieblomme ('Passionflowers' or 'Flowers of Suffering'). ${ }^{22}$ Lesser mortals might have lost their faith in God, but not Totius. Still, it is perhaps understandable that, exhausted by grief, the idea of forgetting and oblivion associated with the Classical myth about the River Lethe should begin to look increasingly appealing to him, particularly as he approached the end of his own life.

\section{Totius' background and education}

Although it is not essential to have had a Classical education to make a reference to the Lethe, it is less likely that thoughts of this mythical river and all its nuances would occur to someone without such a background. As it happens, Totius did enjoy a Classical education, although it was largely ancillary to his Theological studies. He began studying Latin when he attended a German mission school called Morgensonne north of Pretoria during the time that his father, the famous Reverend Stephanus Jacobus du Toit, acted as Inspector of Education for the Transvaal Republic or Zuid-Afrikaansche Republiek (ZAR). ${ }^{23}$ A native of Paarl in the Cape, to which he subsequently returned, S J du Toit was also a leading light in the early struggles to develop the Afrikaans language and was the founder of the Genootskap van Regte Afrikaners ('Society of True Afrikaners') in 1879.24 Exceptionally well educated, S J du Toit could read Latin fluently, and spent much time tutoring his son himself before Totius went to study Theology at the fledgling

20 See Totius' poignant note 'Aan ons vrinde', published in Het Kerkblad on 15 January 1921, in which he explains how this sudden tragedy occurred, and how the family reacted (Venter 1977:473-475, vol. 8). Totius concludes: 'Wat van haar naleef, is die allersoetste herinnerings ...' — 'What survives of her, are the sweetest memories ...' (Venter $i d .: 475)$.

21 D’Assonville 1993:131-132.

22 Totius and his wife Marie (née Postma) had four other children who survived to adulthood, but some years later the death of a granddaughter Annemarie Smit (infant child of his adult daughter Bettie) seems to have reopened the wounds, and he published another volume of verse entitled Skemering ('Twilight', emphasising the idea of failing light), in which, among other things, he mourned once again the passing of a young life. 
seminary of the Gereformeerde Kerk ('Reformed Church') in Burgersdorp. ${ }^{25}$ There studies in Latin, Greek, and Hebrew comprised a significant portion of the syllabus. After successfully completing his undergraduate degree, and acting as chaplain to Boer commandoes in the veld during the Anglo-Boer war, ${ }^{26}$ Totius travelled to the Netherlands to pursue doctoral studies in Theology at the Vrije Universiteit in Amsterdam. He cemented a life-long friendship with a fellow graduate of Burgersdorp, Ferdinand Postma, who studied Classics at the Vrije Universiteit and was later to become Professor of Latin and eventually the first Rector of Potchefstroom University. ${ }^{27}$

It could be argued that, as an academic and writer, Totius had enjoyed sufficient exposure to Classical antiquity for it to be a competing paradigm in his mind. The Classical worldview was one which, as a Christian and staunch Calvinist, and above all as a translator of the Bible, Totius sublimated to a primarily Judaeo-Christian approach. What is fascinating to me about the poem Lei my nie ... is that the poet seriously entertains the idea of existence of the Lethe, the river of forgetfulness, however briefly, and implies that it has some appeal: he has suffered so much grief in his life that part of him longs for oblivion. A recurring theme in Totius' poetry is his rebellion against the Calvinist view of the Christian God, and this sudden appeal to the Classical worldview may be one more form of such rebellion. However, in the third and final stanza of the poem, the poet firmly rejects the possibility of Lethe's existence and the Classical paradigm altogether: Dis 'n skone fantasie ('It's an utter fantasy'). ${ }^{28}$ While he seems to acknowledge that there is something undeniably appealing about the possibility of there being a 'river of forgetfulness', Totius ultimately rejects the whole idea, ${ }^{29}$ concluding that, since he is completely unable to forget his pain,

25 See Totius' recollections of his studies at Burgersdorp ('My Burgersdorpse dae', Venter 1977:480, vol. 8).

26 D'Assonville 1993:65-75.

27 See Totius' biography of Ferdinand Postma, originally published in Koers in November 1939 (Venter 1977:455-463, vol. 8). Ferdinand Postma wrote his doctorate on Virgil's perception of the divine, and later compiled a Latin-Afrikaans dictionary.

28 Stephen Harrison has suggested to me that, in referring to the Lethe and the underworld as a skone fantasie (which could also be translated as a 'beautiful fantasy'), Totius is thinking of the famous 'Gates of Sleep' controversy at the end of Book 6 of the Aeneid, where Aeneas exits the underworld through the Gates of Ivory, the gates of 'false dreams' (as opposed to the Gates of Horn, though which true dreams leave). The implication there is that the preceding images of the underworld (and Rome's future) have been nothing but a beautiful dream.

29 The words Lei my nie ... also recall a line from the Afrikaans version of the Lord's Prayer (Die Here se Gebed) or the 'Our Father' (Die 'Onse Vader'), namely Lei ons nie in versoeking nie ... - 'Lead us not into temptation'. The implication may be that the 
the river Lethe cannot exist. ${ }^{30}$ Of course, in classical antiquity the Lethe was usually reached only after death, but it is striking that, while approaching his own death, the poet has these thoughts.

\section{The little thorn bush right beside the road: Images of Imperial destruction and their aftermath}

Further Classical influences may be detected in Totius' work. A lyric writer who reveals or appears to reveal his innermost emotions and struggles may seem to be composing in the tradition of writers like Sappho and Catullus. ${ }^{31}$ Another of Totius' poems seems to reverberate a topos first employed by Sappho and later by Catullus, where a hapless plant is cruelly destroyed by someone or something passing by:

\section{Vergewe en vergeet ${ }^{32}$}

Daar het 'n doringboompie

vlak by die pad gestaan, waar lange ossespanne

met sware vragte gaan.

\section{Forgive and forget}

There was once a little thorn tree standing right beside the road, where long spans of oxen went with their heavy load.

whole fantasy about the river Lethe and its appealing idea of oblivion is in itself a type of temptation, which the believer should resist.

D'Assonville 1993:18: 'Selfs die Griekse mite met sy Lethe as die stroom van vergetelheid in die onderwêreld, kan Totius se verlede nie in die diepte laat versink nie' ('Even the Greek myth with its Lethe as the stream of forgetting in the underworld cannot allow Totius' past to sink into the depths').

31 It has often struck me that the opening of what is perhaps Totius' most famous poem, which expresses his pain over his daughter's sudden death: O Die pyn-gedagte: My kind is dood! (Venter 1977:229-230 vol.10), has much in common with the first three lines of Catullus 3: Lugete o Veneres Cupidinesque / ... / passer mortuus est meae puellae (1-3), although many have doubted the sincerity and seriousness of the Catullan dirge, given its Hellenistic predecessors. In both cases an emotional cry of pain or lamentation is first uttered, and then the reason for such mourning follows.

32 With this title Vergewe en vergeet ('Forgive and forget'), Totius was ironizing the motto of the South African Party (SAP), which was trying to foster a policy of reconciliation, after the Boer War, between English-speakers and Afrikaans-speakers within the Union of South Africa (see Giliomee 2003:366). Totius' political point seems to be that to forgive and forget is impossible, because the incipient nation of Afrikaans-speakers drawn from the former Boer republics was so permanently scarred by the war and its after effects; they could perhaps forgive, but they would never forget. 
En eendag kom daarlanges

'n ossewa verby,

wat met sy sware wiele

dwars-oor die boompie ry.

'Jy het mos, doringstruikie, my ander dag gekrap; en daarom het my wiele jou kroontjie plat getrap.'

Die ossewa verdwyn weer agter ' $n$ heuweltop, en langsaam buig die boompie sy stammetjie weer op.

Sy skoonheid was geskonde;

sy bassies was geskeur; op een plek was die stammetjie so amper middeldeur.

Maar tog het daardie boompie weer stadig reggekom, want oor sy wonde druppel die salf van eie gom.

Ook het die loop van jare die wonde weggewis net een plek bly 'n teken wat onuitwisbaar is.

Die wonde word gesond weer As jare kom en gaan, maar daardie merk word groter en groei maar aldeur aan. ${ }^{33}$
And one day in that place an ox-wagon came past, and with its heavy wheels wheeled right over the little mast.

'The other day, o thorn-twig, you scratched me with your bough and that is why my wheels came and squashed your little crown.'

The ox-wagon disappeared then over a far hill-crest, and slowly the little tree to stand straight did its best.

Its beauty was in tatters its bark was torn askew; and at one place the little trunk was even snapped half through.

But yet that little thorn tree gradually stood upright healing itself with its own gum the ointment of its plight.

Along with passing years the wounds were wiped away at just one spot there was a scar that irreversible would stay.

The wounds are all healed up again as the decades come and go, but that mark gets larger and yet will always grow.

The image of a plant being destroyed by a wagon is reminiscent of the image of the flower, symbolic of his love, cut down by the plough in the final stanza of

33 Venter 1977:22-23 vol. 10. 
Catullus 11 . This is the poem in which the poet is widely considered by scholars to have bade a final farewell to his faithless mistress, the Lesbia of his poetry. In the first fourteen lines of poem 11, Catullus first addresses two companions (comites) of his, Furius and Aurelius, praising them for being bravely prepared to travel with him all over the known world. He describes in great detail exotic places at the end of and even beyond the Roman sphere of influence, even highlighting Julius Caesar's past successes against the Gauls and recent forays into Britain to extend the Roman imperium. Images redolent of masculine dominance over effeminacy are used, as well as words like 'penetrate', as the processes of conquest and world domination are compared to sexual conquest. After the fifteenth line there comes a surprising, sudden change of focus: Catullus is not actually asking Furius and Aurelius to travel manfully to the ends of the earth; all he wants them to do is run an errand for him, to go and tell his faithless mistress some not-very-pleasant home truths (non bona dicta, 11.16). He then portrays his mistress as a promiscuous, voracious man-eating monster, who, he says, holds three-hundred lovers simultaneously in her thrall, loving none of them truly, and repeatedly rupturing their groins (nullum amans vere, sed identidem omnium / ilia rumpens, 11.19-20) with her relentless sexual insatiability. ${ }^{34}$

This crude image is then followed by pathos: Catullus' love is described as a flower that grew at the edge of a meadow, and which was cruelly and needlessly cut down by a passing plough (11.21-24). Catullus himself was clearly influenced by similar images employed by the ancient Greek poetess Sappho. There are two fragments from Sappho, perhaps both from the same (now lost) poem, in which she talks about plants growing in inaccessible places. These fragments both seem to derive from epithalamic imagery in praise of the bride's valued beauty, purity, and virginity. In one of these fragments (105a, L-P), she speaks of a choice apple growing in a hard-to-reach place, which the pickers were unable to harvest: 'Such as the sweet-apple reddening on a high branch / Right at the very top where the fruit-pickers have overlooked it / Or not exactly overlooked it, but could not reach so high .... ${ }^{35}$ More relevant for Catullus' intertextual borrowing is the next fragment, which, as noted, may be part of the same original poem, and in which Sappho speaks of a hyacinth flower growing high up on a mountain slope, which is destroyed - trampled underfoot - by 'shepherd men' and its purple flower falls to the ground $(105 \mathrm{c})$. In this context the singer was probably trying to warn of and lament the loss of the bride's virginity. The fact that the gender of the shepherds as

34 While Catullus 11.19-20 can be translated in a sexually obscene sense, the lines can be (and often are) translated relatively innocently. The poem has for a long time been part of the standard fare in South African school and university courses which deliberately exclude Catullus' cruder poetry.

35 Trans. DuQuesne 2015:77. 
male is emphasized is probably not accidental $;^{36}$ as shepherds they venture further than average folk, but it as men that they have the power to destroy the flower's rare beauty without any compunction.

Catullus himself adapted this wedding-song topos to his own epithalamium, Poem 62.39-47, where he places the description of the rare flower in the mouths of a chorus of maidens bemoaning the inevitable loss of virginity on the part of the bride. They describe a flower that grows in a protected, secluded garden (in saeptis ... hortis, 62.39), that is unknown to sheep (ignotus pecori, 62. 40 - an oblique reference to Sappho's 'shepherd men'?), torn up by no plough (nullo convolsus aratro, 62.40). The breezes stroke it, the sun strengthens it, and the rain showers nourish it (62.41). It is desired by many girls and boys, but when it is plucked, nipped off by a fingernail (... cum tenui carptus defloruit ungui, 62.43), its pristine beauty is destroyed and no one is interested in it any more.

Critics have made much of the gender inversions of Catullus' adaptation of the flower image to himself at poem 11.21-24. As indicated above, the image is usually applied to virginal girls in wedding hymns, but here Catullus uses it to describe his love, and by implication, himself. The mistress who has just been described as a quasi-masculine, active, dominant, even cruel lover (amans could also refer to the dominant male partner in Graeco-Roman sexual transactions), or, perhaps rather, the system she represents, is now likened to a plough, an instrument of agriculture and progress, but also of the destruction of nature. By contrast, Catullus' love is a defenceless, soft, quasi-feminine victim of her thoughtless destruction. Given the imperial imagery and virile ideas of Roman expansionism ('penetration') in the first part of the poem, recently critics $^{37}$ have begun to see a good deal of anti-imperialist rhetoric in this image. Lesbia's monstrous and aggressive sexuality is aligned with Rome's dominant, relentless policy of conquest and expansionism. Catullus aligns himself with the victims of such colonialising rampage. ${ }^{38}$

It is entirely possible that Totius derived his image of the destruction of the thorn tree from a different or intermediate source, or even from his own experience, but there are a few striking points of comparison between the two images. Like Catullus' flower which grew right at the edge of the meadow (velut

36 DuQuesne 2015:77.

37 E.g. Skinner 1991:9; Konstan 2000:14-16; Greene 2006:56-61; Shapiro 2012:46.

38 Virgil's description of the death of the young Euryalus at Aeneid 9.433-437 is clearly modelled on Catullus 11.21-24 (at Aeneid 9.435, the dying Euryalus is described as a purple flower cut down by the plough: purpureus veluti cum flos succisus aratro), but it also comments on imperialism and its consequences. I thank one of the anonymous referees of Akroterion for this reference. The story of Nisus and Euryalus influenced Milton, whom Totius greatly admired (see Whittington 2010). 
prati / ultimi flos, 11.22-23), Totius' little thorn tree grew right next to the road: Daar het 'n doringboompie / vlak by die pad gestaan (1-2). Unlike Sappho's and Catullus' images, the thorn bush is not a symbol of feminine purity or virginity; rather it seems to be a symbol of national toughness and survival in a relentless environment. The role of the ox-wagon in this story may be confusing for contemporary South Africans, since it was later to become one of the chief symbols of Afrikaner nationalism. It should be remembered, however, that the oxwagon became associated with Afrikaner nationalism only much later in South African history, particularly after the politically motivated staged re-enactment of the Great Trek in $1938 .{ }^{39}$ In this poem, written in the early years of the twentieth century, the ox-wagon does not yet carry these 'nationalistic' associations and is more or less the equivalent of a big truck (or a four-by-four) in today's world. When Totius wrote this poem in the wake of the South African War and as a signal of his opposition to the new policy of reconciliation, the ox-wagon was for him a symbol of British imperialism.

Like Catullus' flower, Totius' thorn bush, growing right next to the road, occupies a liminal space between the bush or the wilderness, on the one hand, and the road, the symbol of progress, communication and civilization, on the other. Just as Catullus' flower at the edge of the meadow could have been left standing, Totius' tree could easily have been spared if the wagon had swerved slightly to avoid it. However, Totius makes clear, with his apostrophe of the bush by the wagon in stanza three, which seems reminiscent of a Greek or Roman fable, that the ox-wagon deliberately drove over the tree in revenge for a previous minor slight: the thorn bush is said to have scratched the wagon when it last rode through there, and in retaliation, the wagon has flattened the little bush. Totius' metaphor, it must be said, has a great deal more venom and spitefulness in it than either Sappho's or Catullus' images. The thorn bush is not just accidentally removed as the concomitant of 'progress' or of some agricultural or pastoral activity, but is deliberately punished for a perceived prior misdemeanour. In Sappho's hyacinth image and in Catullus' flos image at 11.21-24, there is the implication that the destruction is (or may be) accidental. Yet, unlike Catullus' flower, which is utterly destroyed when it is 'touched' by the plough, the thorn tree ultimately recovers, though with a scar, which grows ever larger as the tree itself continues to grow. The destruction and regeneration of the thorn tree are symbolic of the Afrikaner response to the Anglo-Boer War. Thus Catullus' and Totius' images of plant destruction ironically share a curious coincidence in post-colonial anti-imperialist discourse.

39 See now the discussion of the reconstructed second 'Great Trek' on the supposed centenary of the first one in 1938 by Rankin \& Schneider in Parker 2017:143-144. 
Totius' plant image is far more obviously and consciously political than Catullus'. It is also informed by (but appears to rebel against) mainstream Christian ideology, which promulgates forgiveness, an injunction with which, Totius suggests, his nation may be unable to comply. The scar that grows ever larger with the tree itself makes forgetting impossible. Lindenburg (1965:45) suggests that Totius' tree growing right next to a road with so much traffic, is an historical reference to the British Imperial negotiations, before the War, for land to build a railway-line from Cape to Cairo. Just like the tree that appears to obstruct widening the road, the Boer Republics stood directly in the way of the arch-Imperialist Cecil John Rhodes' vision of the road to the North. ${ }^{40}$ The occasion on which the little thorn tree scratched the wagon, I would go so far as to suggest, may even refer specifically to the Transvaal Republic's repulsion of the infamous Jameson Raid. This took place before the War, when in 1896 Rhodes' friend Leander Starr Jameson led an illegal invasion of the sovereign South African Republic supposedly in order to support an 'Uitlander' (resident alien) rebellion timed to erupt simultaneously. The rebellion never took place, and the Raid was successfully repelled by Paul Kruger's government. The result was embarrassment for Rhodes and a thwarting of his Imperial aims: the Cape-to-Cairo Railway has yet to be built. Alternatively, the 'scratch' may have referred to the previous, much shorter war between the Boer Republics and Britain, also known as the First Anglo-Boer War (December 1880 - March 1881), which took place about twenty years earlier and in which the Republics were victorious, or at least successful in getting Britain to back down.

However, Totius' bitter anti-imperialist imagery has an ironic postscript, as has been pointed out by Gerrie Snyman of UNISA. ${ }^{41}$ He argues that Totius' poem Vergewe en vergeet still has relevance in contemporary South Africa, not so much for Afrikaners and other white South Africans as Totius would have defined them, but for Black South Africans, who had to bear the brunt of the Apartheid system that was instituted after the electoral victory of the right-wing Afrikaner-led Nationalist Party in 1948. This was a party and a policy with which Totius' nationalist sympathies and Calvinist approval of isolation were in tune and that he arguably helped foster, even if he personally could not have foreseen all the consequences of his ideology. The thorn tree, if I may extend the metaphor, ultimately grew up to become as dominating as the wagon, and destroyed other thorn bushes which were desperately hanging on for survival. As a result of the formal end of Apartheid, the introduction of democracy and the shocking

40 Rhodes is arguably a figure analogous (at least in his own mind) to Catullus' Caesar in poem 11.

${ }^{41}$ Snyman 2015:229. 
revelations of abuses during the Truth and Reconciliation Commission after 1994, a new group of South Africans had to face the question of forgiving and forgetting, sometimes in a very public forum. In most cases, they seem to have agreed with Totius: forgiveness is sometimes possible, but forgetting is not always easy or even desirable. In the words of Nelson Mandela: 'We recall our terrible past so that we can deal with it, forgiving where forgiveness is necessary - but not forgetting. By remembering, we can ensure that never again will such inhumanity tear us apart, and we can eradicate a dangerous legacy that still lurks as a threat to our democracy. ${ }^{42}$

In conclusion, the Classical worldview, although part of his background, was not a major concern for Totius, but the images of the Classical world did have some influence on his poetry, either directly or indirectly. Both the poems I have discussed here deal with issues of memory and forgetting: the first was from Totius' last years and was concerned with personal grief and forgetting, and the second was an earlier poem that may possibly have used and extended a Classical metaphor to make a political point. A final question should be whether the later poem, Lei my nie ..., quoted first above, does not perhaps deliberately evoke the earlier, political poem ironically titled Vergewe en vergeet. Although I have interpreted Lei my nie ... as referring to personal grief, for many Afrikaners the losses of the Anglo-Boer War, particularly the deaths of many women and children in the concentration camps, were both personal and political. The last line of Totius' last poem stresses the impossibility of forgetting, and in either case, I think, the poet emphasised the importance of remembering. ${ }^{43}$

\section{BIBLIOGRAPHY}

D’Assonville, V E 1993. Dit is Totius: $J$ D du Toit 1877-1953. Weltevredenpark: Marnix.

D'Assonville, V E 2003. 'Non sine laude': Totius se doktorsgraad 1903. Die Kerkblad April 2003:51-52.

Du Toit, A 1985. Puritans in Africa? Afrikaner 'Calvinism' and Kuyperian NeoCalvinism in Late Nineteenth-Century South Africa. Comparative Studies in Society and History 27:203-240.

DuQuesne, T (ed., trans.) 2015. Sappho of Lesbos Poems. London: Darengo Publications.

42 Mandela 1999, cit. Snyman 2015:35. Note the plant imagery appearing again in 'eradicate'.

43 An earlier version of this article was read at the UNISA Colloquium held in Centurion in October 2017. I thank the referees of Akroterion for their useful comments, suggestions and edits. Any remaining errors are my own. 
Cloete, T T 1990. Simboliek in Totius se werk. Literator 11:77-90.

Cloete, T T 2000. Teologiekroniek - Totius se vertaling van die Psalms in die Bybel en sy beryming daarvan. Skrif en Kerk 21:194-200.

Coassin, F 2000. The Function of Lethe. In Baker, M \& Glenn, D (edd.) Dante Colloquia in Australia: 1982-1999, 95-102. Adelaide: Australian Humanities Press.

Giliomee, H B 2003. The Afrikaners: Biography of a People. London: Hurst \& Co.

Greene, E 2006. Catullus, Caesar and Roman masculine identity. Antichthon 40: 49-64.

Innes, M M (ed., trans.) 1955. The Metamorphoses of Ovid. Harmondsworth: Penguin Books.

Konstan, D 2000. Sex, self, and empire in Catullus: The construction of a decentered identity. Diotima: Materials for the Study of Women and Gender in the Ancient World (published online:

http://www.uky.edu/AS/Classics/gender.html). (last accessed 21/12/17).

Lindenburg, E 1965. Onsydige toets: Letterkundige opstelle. Cape Town: Academica.

Mandela, N R 1999. We should forgive but not forget. The Guardian 3 July 1999.

Milton, J 1674. The project Gutenberg EBook of Paradise lost. Posting date: 2 March 2011 [www.gutenberg.net]. (last accessed 21/12/17).

Rankin, E \& Schneider, R M 2017. 'Copy nothing': Classical ideals and Afrikaner ideologies at the Voortrekker Monument. In Parker, G (ed.) 2017. South Africa, Greece, Rome: Classical Confrontations, 141-212. Cambridge: Cambridge University Press.

Shapiro, S O 2012. Love and war at the ends of the earth (Catullus 11). Mediterranean Chronicle 2:31-50.

Skinner, M B 1991. The dynamics of Catullan obscenity: cc. 37, 58 and 11. Syllecta Classica 3:1-11

Snyman, G 2015. Totius: Die ironie van vergewe en vergeet. LitNet Akademies 12.2:211-235.

Venter, H et al (eds.) 1977. Totius: Versamelde werke vol. 6: Strominge Cape Town: Tafelberg.

1977. Totius: Versamelde werke vol. 8: Onderwys, boekbesprekings, biografieë. Cape Town: Tafelberg.

1977. Totius: Versamelde werke vol. 10: Gedigte en prosa. Cape Town: Tafelberg.

— 1977. Totius: Versamelde werke vol. 11: Die berymde Psalms, skrifberymings, register. Cape Town: Tafelberg.

Whittington, L 2010. Vergil's Nisus and the language of self-sacrifice in Paradise lost. Modern Philology 107:588-606. 